\title{
A COMPOSIÇÃO DE UM ÁLBUM FOTOGRÁFICO: OS RASTROS DE UMA AVÓ MATERNA
}

\section{CRISTINA MARIA DA SILVA}

Universidade Federal do Ceará

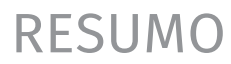

Na montagem de um álbum de fotografias busco um rosto familiar: uma mulher de vestido azul, chamada Tereza, minha avó materna, descubro os laços que compõem a sua vida, os sonhos, as flores de sua preferência, os modelos de seus vestidos, os rastros que seus passos deixaram nas lembranças de infância de uma criança, as narrativas dos que com ela conviveram. Um álbum é pensado como uma construção narrativa e imagética de múltiplas grafias: daqueles que de modo separado realizaram as fotos, as descontinuidades do tempo que as mantiveram separadas, dos conhecimentos, narrativas e sentidos que elas evocam ao olhar, de sua conjugação entre temporalidades. Através da recuperação de imagens para montar um álbum, podemos criar, descobrir, desvelar conhecimentos, acender experiências. Contamos com a noção de fotobiografias (Fabiana Bruno, 2009); com o olhar sobre a imagem e suas supervivências (Didi -Huberman, 2011) e com Étienne Samain (2013), quando nos instiga a descobrir as peles da imagem e a acompanhar o que elas pensam. Na composição de um álbum, compomos uma origem, desbravamos a história de uma mulher, bem como de suas narrativas, que se inscrevem nas dedicatórias escritas em seus versos e nos caminhos que as imagens trilharam, em muitas mãos, até se encontrarem, em um álbum de fotografias.

Palavras-chave: Álbum de Família. Fotobiografia. Imagens. Narrativas.

\section{ABSTRACT ASSEMBLING A PHOTOGRAPH ALBUM: THE TRAJECTORY OF A MATERNAL GRANDMOTHER}

Assembling a photograph album, I seek a familiar face: a woman in a blue dress, named Tereza, my maternal grandmother. I discover the threads that weave her life: the dreams, her preferred flowers, the pattern of her dresses, the tracks left by her steps left in childhood memories. An album is thought as an imagery and narrative construction of multiple inscriptions: of those who separately took the pictures, the discontinuities of time that have kept them apart, of 
the knowledges, narratives and meanings they evoke to the observer, their conjoining of temporalities. Through the recovery of images to assemble a photo album we can create, unveil, reveal knowledges, lighten up experiences. Counting on the notion of photobiographies (Fabiana Bruno, 2009); with the gaze upon the images and their survival (Didi-Huberman, 2011), and with Étienne Samain (2013), when he instigates us to uncover the skins of the image and to follow what they think. In the composition of an album we unravel the history of a woman, as well as the narratives that it unfolds, inscribed in the dedications on the back of the photographs and through the multiple paths and hands those images have passed by until they found each other.

Keywords: Family Album. Photobiography. Images. Narratives.

En el montaje de un álbum de fotografias de familia busco un rostro familiar: una mujer de vestido azul, llamada Tereza, mi abuela materna. Descubro los lazos que componen su vida, sus sueños, las flores de su preferencia, los modelos de sus vestidos, los rastros que sus pasos dejaron en mis recuerdos de la infancia. Un álbum es pensado como una construcción narrativa e imagética de múltiples grafias: de aquellas que de modo separado realizaran las fotos, las discontinuidades del tiempo que las mantuvieron separadas de los conocimientos, narrativas y sentidos que ellas evocan al mirar, de su conjugación entre temporalidades. A través de la recuperación de imágenes para montar un álbum, podemos crear, descubrir, desvelar conocimientos, animar experiencias. Contamos con la noción de fotobiografias (Fabiana Bruno, 2009); con el mirar sobre la imagen y sus supervivencias (Didi-Huberman, 2011) e con Étienne Samain (2013), cuando nos instiga a descubrir las pieles de la imagen y a acompañar lo que ellas piensan. En el montaje de un álbum, componemos un origen, exploramos la historia de una mujer, bien en sus narrativas, que se inscriben en las dedicatorias escritas, en sus versos y en los caminos que las imágenes siguen, en uchas manos, hasta que se encontraron en un álbum de fotografias.

Palabras clave: Álbum de Familia. Fotobiografia. Imágenes. Narrativas. 
0 rastro inscreve a lembrança de uma presença que não existe mais e que sempre corre o risco de se apagar definitivamente.

Gagnebin (2006, p. 44)

\section{Onde se grafa uma vida? Um exercício antropológico na composição de um álbum fotográfico}

A antropologia não é etnografia, desafia Tim Ingold (2015). Assim, busco compreender a antropologia como prática que se debruça na crítica do ser e saber humanos, em suas condições e potencialidades. Compreender como construímos escritos sobre como os outros se narram, implica entender que narrar a vida é parte do empreendimento que todos nós nos lançamos, ainda que nem sempre pensemos nas combinações narrativas que montam os textos que construímos. Escrevemos sobre nós mesmos, ao escrevermos sobre os outros? Onde se grafa uma vida? Muitas vezes estamos narrando a nós mesmos.

Lançamos mão das noções de grafia, narrativas e trajetórias, para seguir a composição de um álbum de fotografias e nele desbravar a história de uma mulher, assim como exercitar, nesse percurso, as potencialidades da imagem adormecida num álbum fotográfico para a experiência antropológica. Grafia é aqui tomada como a possibilidade de se escrever sobre uma vida, sobretudo, quando a tomamos pelas imagens, uma escrita que contorna, mais do que recupera ou restitui uma existência. Narrar é aqui entendido como contar, fazer conhecer ou fazer alguém conhecedor de algo. Quem narra conhece, fala de algo ou de alguém. Acompanhar uma trajetória é, aqui compreendido, como estar atento ao que atravessa uma vida, o que não quer dizer que reconstruamos uma vida, mas apenas reunimos experiências que nos permitem conhecer as relações nas quais essa vida esteve inserida. Acionamos enredos que nos permitem entender as tramas dessa vida, ainda que não totalmente a composição de seu enredo.

Tereza (1913-1984), a personagem central desse trabalho, não tinha um álbum, nesse sentido, esse trabalho também é a montagem da vida dela através de fotografias. Assim, esse trabalho consiste em reunir essas imagens, descobrir suas narrativas e conhecer as experiências que compuseram sua vida. Nesse sentido, para esse trabalho "Foi preciso, portanto, perseguir rastros, tênues no início, mais densos depois [...]", como sugere Kofes (2001, p. 21), pois trinta e dois anos depois da morte de Tereza, temos como traços de sua existência alguns objetos pessoais, as fotografias e as histórias de seus filhos, para desvelar as grafias de sua vida. Artefatos, imagens e imaginação de uma vida. Pensar nesses encontros é pensar nos vínculos entre as pessoas que aparecem nas imagens, as relações que tecemos com nossos antepassados, mas também refletir sobre as raízes de nossos comportamentos e ações, olhando e conhecendo o outro, que, ao mesmo tempo, é distante, ausente e familiar.

Partimos do entendimento de que a fotografia é um arquivo vivo do tempo e compõe as peles de nossa existência. Como arquivo, reúne e congrega imagens, como articulações, conjugações e declinações de nossas aventuras humanas (SAMAIN, 2013). Um álbum é uma extensão de nossos corpos. Nele estão reunidas fotos daqueles que estão entre nossos laços de afeto, inscrevemos suas histórias e prolongamos suas existências através de suas imagens, das palavras que ainda resistem sobre eles nas lembranças. As imagens interligam-se aos nossos corpos, como memória afetiva, desvelando o que deles sobrevive, o que deles ainda se revela, em nossas práticas, em nossa própria fisionomia. 
0 que as imagens pensam e desvelam por detrás delas mesmas, que histórias elas nos contam, adornadas das narrativas que evocam? Que enredos propiciam? O álbum é aqui pensado como uma das linhas vitais que costuram e enredam a vida e suas relações num mundo narrado (INGOLD, 2015). Que pedaços de coisas heterogêneas e anacrônicas sobrevivem nas imagens? (DIDI-HUBERMAN apud BRUNO, 2012, p. 97).

Em um álbum de fotografias, pedaços da vida sobrevivem das lembranças de uma trajetória. Na imagem, tudo o que evoca essa vida recupera uma temporalidade heterogênea e fragmentada, ressurgem lugares e situações onde cada um recorda de um pedaço do que foi uma história de uma vida, ainda que essas sobrevivências não nos permitam recuperar uma inteireza do vivido, e nem essa história seja, claro, um todo coerente. O que aqui, sobrevive, sobre Tereza, é montado por palavras e pelas imagens escolhidas, mas é um processo contingente, pois outras escolhas poderiam ser feitas, o fato é que a cronologia explode ao mergulharmos na sua existência. Quando montamos uma vida, pelas composições de imagens que dela se preservam, lidamos com uma "exposição de anacronias" (BRUNO, 2012), ou seja, a união de tempos, objetos, palavras e imagens, advindos de tempos e narrativas diversos.

As fotografias de um álbum, afirma Fabiana Bruno, têm uma curta vida visivel, adormecem no silêncio dos álbuns, nas caixas de lembranças e nos arquivos. 0 que elas podem despertar e o que nelas se grafa? Labirintos de signos? Figuras, palavras, silêncios, contextos? Quais? A fotografia de um álbum faz explodir, reacende histórias e lembranças. Acompanhando as noções de montagem, desmontagem e remontagem (BRUNO, 2012), pensamos no tipo de conhecimento que a imagem pode nos trazer. Mas, sobretudo, como ela pode nos fazer pensar o próprio fazer antropológico e sobre quem somos, quando pesquisamos. Onde estamos, quando fazemos pesquisa? Como se dão os nossos encontros com as narrativas que descobrimos, quanto delas nos inscrevem no que fazemos?

Montar quer dizer subir uma montanha, projetar, ascender, colocar-se sobre. Olhando para Tereza, surge uma mulher como uma lembrança, os vestidos que usava, a medalha (da congregação Filhas de Maria), que carregava em volta do pescoço, as flores que gostava, no Ceará, chamadas de riso, mas conhecidas como buganvília ou primavera. Nas imagens também vemos as pessoas com quem conviveu. Nas fotos, os poucos registros de sua passagem, as pessoas com quem Tereza conviveu: quase sempre ao lado do marido, os filhos gerados, os netos, ao redor de sua casa. As fotos geralmente são feitas fora de casa, todas no claro, por causa da ausência de flash, na época, nas máquinas Kodak, utilizadas para a realização de muitas das fotos que tenho, como me explicou Gorete, a filha mais nova de Tereza.

Ao ressurgir no movimento das fotos, o primeiro acontecimento é a explosão da cronologia, seus passos se montam pelos vestígios que ficaram de sua existência na memória. Ela se compõe pela notícia de sua morte, pelas pessoas que ainda lembram dela, pelas lembranças turvas de seus gostos e fazeres. Assim, as imagens montam uma existência, nossos relatos também são montagens, composições de temporalidades, fatias da vida colhidas de pessoas, seus gestos, objetos e acontecimentos.

Onde se grafa uma vida? Na escrita, nos bordados, numa costura, numa pintura, num álbum de fotografias? Em combinações: vidas e poesias, fotos e esculturas, comidas e relatos, colcha de retalhos e narrativas?

Gagnebin lembra-nos que o "[...] rastro inscreve a lembrança de uma presença que não existe mais e que sempre corre o risco de se 
apagar definitivamente [...]". (GAGNEBIN, 2006, p. 44). Falar em rastros, penso que de uma pessoa, de um acontecimento, de uma experiência é também falar, a partir do que a autora aponta, em memória, o que guardamos, lembramos, esquecemos, e também de escrita, sobre como escrevemos a respeito de uma vida e suas alteridades.

Quando pensamos em olhar um álbum de fotografias, ou melhor, em montar um álbum de fotografias, e procurar os vestígios de uma pessoa através dele, como buscamos, ao procurarmos conhecer Tereza, é um caminho para pensar na fragilidade desse rastro, que se exprime nas fotos já desgastadas pelo tempo, nas marcas que carregam, por terem ficado expostas em quadros, amassadas em álbuns que viajaram por vários lugares e mesmo ficaram adormecidas, guardadas pelos que a conheceram. Os detalhes das imagens permitem-nos olhar os sinais da passagem do tempo, os encontros que perpassaram essa vida, os objetos que ainda sobrevivem, como rastro do que foi usado, tocado, experimentando por quem só existe na lembrança. Sinais e indícios de uma imagem permitem-nos que toquemos na realidade que a imagem nos dá, uma realidade fugidia, mas uma zona privilegiada onde ainda é possivel pensar sobre a existência de uma vida (GINZBURG, 1989).

A imagem, a seguir, de Tereza, é de setembro de 1982, as suas flores favoritas dissolvemse como se não pudessem mais resistir à passagem do tempo, ela e as flores se esvaindo com o tempo, mas fixadas na imagem digitalizada, como se fosse possivel parar a ação do tempo, para poder pensá-lo, para trazer a vida de Tereza à tona e suas vivências. Entre essas flores borradas pelo tempo, sua existência ressurge, os rastros do tempo tocam a barra do seu vestido, tocam seus ombros, falam de quando nem existia tempo e quando Tereza apenas vivia.
Fig.01 - Tereza e as flores (setembro de 1982).

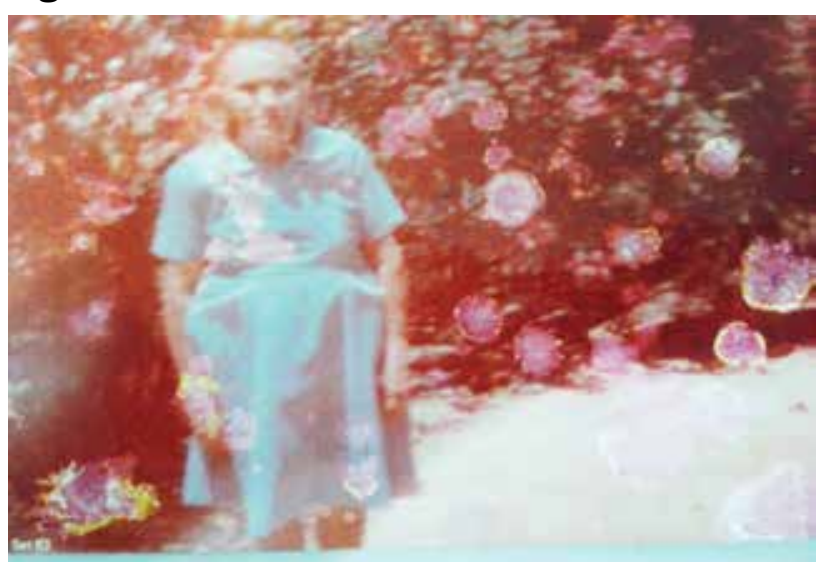

Fonte: Acervo familiar.

Para olhar, sugere-nos Didi-Huberman, é preciso cavar e escavar os próprios olhos, e, sobretudo, saber fechá-los para poder ver melhor. "O olho sempre aberto e desperto [...] torna-se seco. Um olho seco veria talvez tudo o tempo todo. Mas olharia mal. Para olhar melhor nos são necessárias - paradoxo da experiência - todas as nossas lágrimas [...]" (DIDI -HUBERMAN apud CASA NOVA, 2014, p. 65).

Cavando e escavando os próprios olhos ou fechando-os para melhor ver, descobrimos que nem tudo se dá pela imagem, muito do que queremos saber tem rastros nas imagens, mas também precisa dos suportes das narrativas, do que elas podem nos dizer, do que nem sabem que dizem. É como se, para ver melhor a imagem, fosse realmente preciso fechar os olhos, sobretudo, da razão, para escutar os ruídos do tempo, sentir os espaços que ainda parecem aquecidos com a presença e capturar ainda os sons que soam distantes por detrás das portas e dos cômodos da casa já inexistente. Num caminho semelhante ao de Didi-Huberman (2011), o escritor Mia Couto nos lembra que: "Certas coisas vemos melhor é com olhos fechados" (COUTO, 2003, p. 61).

Através do conjunto de fotos que compõem esse álbum de Tereza, criamos um arquivo, uma origem, um começo, e porque não dizer uma ordem para contar a composição de uma vida. Retomar os lugares do álbum de fotogra- 
fias na configuração da vida é também pensar do que se quer e do que não se quer lembrar. Nem sempre os dedos inquiridores serão compreendidos, ao tentarem recuperar a história de alguém, de uma mulher, no caso, nordestina, moradora de uma cidade interiorana, invisivel, praticamente anônima diante da história, mas não menos importante na construção de um olhar que privilegie a singularidade como ponto de partida, sem perder de vista uma escala macroscópica.

Como exprime poeticamente Inês Pedrosa:

Ninguém quer lembrar-se de nada. Não gostaram dos meus dedos inquiridores sobre uma fotografia. 0 guia-intérprete que me acompanhava ia-me dizendo que tivesse paciência, que fosse perguntando devagar, com jeito. (PEDROSA, 2011, p. 195).

"Como ela reuniu tantas fotos da mamãe?" - essa frase ouvi, como se eu não estivesse presente, por uma das filhas de Tereza, dirigida para as outras que estavam presentes, num encontro familiar, em 30 de janeiro de 2016. As imagens imprimem em suas películas um devir, a perda temporal e da presença parecem não existir, há uma sobrevivência nelas que reacende com o olhar. Somos apreendidos pela distância, mas, ao mesmo tempo, é uma experiência de atualização da vida e de seus sentidos, no presente, reconstituindo-a, investindo na perda um gesto de aparição e de renegociação com o passado e, por que não dizer, com o próprio presente e o futuro.

\section{Rastros: recompondo a existência de Tereza}

Como recompor as experiências de uma vida? Seguindo seus rastros. A noção de rastros é aqui apropriada como imprescindivel para pensar a recomposição de uma vida e da experiência antropológica. Sobretudo, ao pensarmos as fragilidades dos rastros, desses que se apagam, que desvanecem na imagem fotográfica.

Benjamin (2009) retoma os rastros como a possibilidade de ler a sociedade que se monta com o aparato administrativo moderno, para ler os vestígios das pessoas envoltas na formação da sociedade burguesa. Para isso, ele retoma Honoré de Balzac, Edgar Allan Poe, Franz Kafka, entre outros, para percorrer os passos e o que se deixa pelo caminho, na configuração de uma nova ordem social e cultural. Desse modo, Benjamin retoma os rastros.

Os rastros da civilização que anota nas praças públicas a hora e a partida dos fiacres, que conta o número de cartas, que numera as casas, que mapeia as ruas, que, através de estojos, caixinhas, mínimos pertences que são utilizados para registrar e conservar rastros individuais no cenário social que se delineia. "O Rastro é a aparição de uma proximidade, por mais longínquo que esteja aquilo que o deixou. [...] No rastro apoderamo-nos da coisa..." (BENJAMIN, 2009, p. 490).

Em Benjamin, o simples nome das ruas torna a cidade um "cosmos linguístico". (BENJAMIN, 2009, p. 563). Percorrer os rastros de uma vida ou os rastros de uma cidade ou de um conhecimento é percorrer minuciosamente um caminho que não está feito, mas que se faz pelos restos, pelos resíduos deixados pelo caminho, o que nos torna narradores e catadores, como sugere Gagnebin (2006), procurando sentidos no que os outros deixaram sobre suas vidas, sobre seus passos. Desse modo, os rastros em Benjamin, e aqui tomados por nós, levam em conta a intrínseca relação entre os passos individuais e coletivos, tanto de quem olhamos, como de nossos próprios passos buscando compreender as composições linguísticas, sociais e culturais do que observamos.

Por meio da noção de sinais e rastros também Ginzburg $(1989 ; 2007)$ retoma um paradigma, que percorre as fronteiras entre o raciona- 
lismo e o irracional. Um patrimônio cognoscitivo que se remete aos caçadores, aos críticos de arte e ao trabalho psicanalítico ou mesmo um trabalho arqueológico que busca "pistas talvez infinitesimais", que permitem "[...] captar uma realidade mais profunda, de outra forma inatingivel. Pistas: mais precisamente sintomas (no caso de Freud), indícios (no caso de Sherlock Holmes), signos pictóricos na arte (no caso de Morelli) [...]" (GINZBURG, 1989, p. 150).

Os sinais em Ginzburg buscam os gestos inconscientes, onde faro, golpe de vista e intuição são elementos imprescindíveis, que percorrem a relação entre rastros e narração, onde os labirintos da realidade se projetam através do fio do relato, dos silêncios e do que sobra. Olhares sobre objetos, pessoas, eventos; o que caracteriza este saber é a "[...] capacidade de, a partir de dados aparentemente negligenciáveis, remontar uma realidade complexa não experimentável diretamente [...]" (GINZBURG, 1989, p. 152).

$O$ rastro inscreve a possibilidade de uma legibilidade. Percorrer em busca de rastros ou decifrá-los é tão importante quanto também recolher os restos. Os rastros são deixados ou esquecidos, falando rigorosamente, afirma Gagnebin (2006, p. 113): "Rastros não são criados - como são outros signos culturais e linguísticos -, mas sim deixados ou esquecidos". Rastros e escrita estiveram muitas vezes entrelaçados, vistos como se fossem sinônimos, mas a escrita não é a única forma de produzir rastros sobre a existência humana, é uma delas, é a presença de um signo. 0 rastro:

É fruto do acaso, da negligencia, às vezes da negligência, às vezes da violência; deixado por um animal que corre ou por um ladrão em fuga, ele denuncia uma presença ausente - sem no entanto, prejulgar sua legibilidade. Como quem deixa rastros não o faz com intenção de transmissão ou de significação, o decifrar dos rastros também é marcado por essa não-intencionalidade. 0 detetive, $\mathrm{o}$ arqueólogo e o psicanalista, esses primos menos distantes do que podem parecer à primeira vista, devem decifrar não só o rastro na sua singularidade concreta, mas também tenta adivinhar o processo, muitas vezes violento, de sua produção involuntária. (GAGNEBIN, 2006, p. 113)

A partir do álbum fotográfico, pensamos na possibilidade de mergulhar nos rastros que nos levam à biografia de Tereza, desvelar suas experiências e o que dela sobra ou sobrevive nas narrativas dos que com ela conviveram. Torna-se importante para nós pensar em experiências e em sobrevivências, do indivíduo e de suas estórias, pois igualmente se abre o desafio de também pensar nessa singularidade em sua relação com a História. Uma tentativa de escala que não perca o fio entre as singularidades, muitas vezes, invisíveis, e a história, no seu sentido macroscópico, rotineiramente visível.

Através de fios de sua história, através das fotos, percorremos a morte de Tereza, a sua vida e seus trajetos. Sua existência mostra-se uma paisagem, onde formas, expressões gestuais e relações são reconstituíveis pelo que as imagens mostram, pelas narrativas ainda existentes e também pelo trabalho da imaginação. Alinhavo aqui as fotos, os objetos, as narrativas e lembranças que grafam que Tereza existiu, ainda que sua biografia aqui apareça como suas imagens, sombreadas pelo tempo, pelos esquecimentos e pelo que não é mais possivel conhecer de sua história.

A grafia de seu nome é algo peculiar, em vários documentos, confunde-se a escrita de seu nome entre: Teresa e Tereza, Tereza Maria Carneiro, Teresa Maria Carneiro, Tereza Maria de Jesus, Teresinha de Jesus Carneiro, Teresa Maria da Conceição, Tereza Maria da Conceição, bem como não é precisa a data de seu nascimento, nos registros oficiais. Em um dos registros civis da cidade de Meruoca-CE, em uma cópia de certidão de casamento, Tereza apa- 
rece como natural de Meruoca-CE e nascida na data de 19 de maio de 1912, mas ela nasceu em 20 de maio de 1913, em Massapê, e viveu até 11 de março de 1984; era filha de Francisco Teixeira da Mota e Maria do Livramento de Jesús.

\section{Arquivar a vida? Álbuns fotográficos, cartas, diários...}

0 arquivo, na sua etimologia, do grego arkhé (começo), é um começo ao qual se debruçam o arqueólogo, o arquiteto, o caçador, o antropólogo, entre outros, para os mais diversos fins. 0 arquivo é também um recomeço, já que, como diz Etienne Samain (2013), não se trata apenas de um mergulhar no passado, nem está fadado a permanecer num lugar de exumação, mas também é a possibilidade de construção de um devir, pois o arquivo também nos interroga. Um arquivo é uma memória encoberta, latente. Arquivos do tempo, arquivos do espaço, arquivos que falam de pessoas, de eventos, a partir de minúsculos fios que desvelam:

\footnotetext{
Memórias que, de novo, trabalham, que reacendem velhas lembranças e outras imagens e, com elas, sobretudo, interrogam nosso tempo presente. Essas fotografias, essas imagens não são mais simples objetos, nem meras lembranças. São questões e questionamentos postos [...]. Elas são uma espécie de clarão na noite, um grito, um apelo, ao mesmo tempo recordação e convocação para aqueles que somos e para outros que nunca chegaremos a conhecer. Memórias que não morrem, que viajam, inquietas. (SAMAIN, 2013, p. 9)
}

O álbum seria uma forma de ver as organizações familiares, as composições étnicas, as apropriações e trajetos pela cidade, a partir das imagens construídas e registradas e das experiências relatadas. Como "escalas do mundo" (SONTAG, 2004), as fotos são testemu- nhos, interpretações, desvelam experiências. As fotos podem contar biografias de uma pessoa, mas também de um grupo social, de suas práticas, de uma cidade, até mesmo a biografia do orvalho, se as imaginarmos com Manoel de Barros (1998).

O álbum fotográfico é um arquivo, nele arquivamos a vida (ARTIÈRES, 1998), arquivamos a nós mesmos, e este ato é pensado, não só como individual, mas como uma injunção social; inscrevemo-nos a todo instante na sociedade e nas cidades onde vivemos, através dos registros civis, das fichas médicas, escolares, bancárias e dos álbuns fotográficos, hoje não mais apenas impressos, mas também virtuais. Um álbum, através de sua brancura, da visibilidade que pretende colocar diante de nossos olhos, permite catalogar identidades, diferenças, diversidades, desigualdades. Nas dobras das fotografias inscrevem-se lacunas, agregam-se registros, que podem ser evocados, quando aliamos, à pesquisa com imagens, a valorização das narrativas. 0 álbum é assim pensado como um campo de pesquisa, nele estão contidos o olhar de quem guardou as imagens e as lembranças que sobreviveram, registrando a configuração de existências individuais e coletivas. Como aponta Armando Silva, outro estudioso dos álbuns fotográficos:

O álbum conta histórias, mas não somente sobre fotos, pois a ele são acrescentados outros objetos, cartões, lembretes, recortes de jornal, relíquias e partes do corpo: umbigos de recémnascidos, gotas de sangue, mechas de cabelo, unhas de mãos e marcas de pés. Em sentido literal, o álbum é um pedaço de nossos corpos. (SILVA, 2008, p. 18)

Aos álbuns se agregam dedicatórias que lembram que alguém traz uma foto e dá para outro, ou lembra dos que estão distantes, e que não tendo a presença física, só lhes resta a imagem fotográfica como elo com a família. É uma lembrança para quem fica, daqueles que 
estão distantes, partem em uma viagem, mudam de cidade ou saem desta vida.

As anotações no verso das fotos são reveladoras, inscrevem pessoas, eventos na história da família e de suas singularidades. Acionam a ação de lembrar; atuam no sentido de que as pessoas não se esqueçam das outras, dos seus pertencimentos e de seus lugares de origem, além da imagem, agregam-se as notas, as dedicatórias, o envio das fotos por cartas, em mãos, ou através de parentes, amigos, conhecidos.

A escritora portuguesa Inês Pedrosa constrói em Nas tuas mãos, uma história sobre a sociedade portuguesa a partir das narrativas de três mulheres: uma avó, uma filha e uma neta, tomando como referência: um diário, um álbum e as cartas. O Diário da avó, Jenny, o álbum da filha Camila e as cartas da neta Natália. Nestas narrativas desvelamos a sociedade que as cercam e suas clausuras, como também desvelamos a intimidade dessas mulheres, suas histórias e as heranças que elas transmitem, umas às outras, de seus sonhos, seus desejos e vivências. "Viver era lembrar continuamente até à náusea, devolver visitas, celebrar nascidos e finados [...]" (PEDROSA, 2011, p. 66).

No álbum de fotografias de Camila, não temos nenhuma imagem, mas a descrição das vivências; temos um álbum escrito, onde as palavras desenham as cenas experimentadas e as pessoas com quem ela conviveu.

Nas suas fotos, Camila vê a si mesma, confronta-se com sua mãe e com a sua filha:

Custa-me muito olhar para esta fotografia da minha filha mulher. Tenho álbuns dela em bebé e menina; na adolescência, passei a fotografá-la menos e, sobretudo, a esquecer-me de organizar as fotografias. Muitas vezes, aliás, nem cheguei a revelar os rolos. [...] A verdade é que não gosto que Natália tenha crescido. É mais bonita do que eu, mais inteligente, e, sobretudo, mais feliz. E insultuosamente jovem. É isso que que não gosto de ver. (PEDROSA, 2011, p. 125)
A fotografia confronta-nos com o outro, visibiliza o que não queremos ver, quando nos incomodam, não olhamos para elas, nós as confinamos num álbum fotográfico escondido num fundo de uma gaveta, oculta por baixo de outras fotografias, guardadas em envelopes, dentro de armários, esquecidas, em alguns casos, quando não são cortadas, rasgadas, afastadas do olhar.

As fotografias também são para Camila a possibilidade de encontrar a si mesma, através do autorretrato. Ela exprime: “Decidi então fazer este a autorretrato, memória do instante em que realmente comecei a gostar de mim [...]" (PEDROSA, 2011, p. 132) A imagem fotográfica é uma maneira de Camila reconstituir a si mesma, reconhecer os seus méritos, nem sempre reconhecidos em seu trabalho profissional. Diante de seu autorretrato, ela exprime:

Gosto dessa mulher de olhos cinzentos cercados por olheiras roxas, cavadas. Gosto das sobrancelhas ralas desta mulher, das rugas que lhe reduzem a cor dos olhos a um traço de luz. Gosto das suas faces cavadas, do queixo demasiado agudo, os ossos quase à transparência da pele. Gosto desta boca lisa, sem cor nem volume. Gosto das dobras deste pescoço como de um mapa esborcinado depois de muitas viagens. Esta mulher imprimiu-se inteira na sua vida e sabe que vai morrer. Ninguém pode já fazer-lhe mal, ninguém pode sequer já fazer mossa sobre o seu corpo excessivamente leve. (PEDROSA, 2011, p. 133)

Natália, a filha, através de suas cartas, declara o que descobre através das fotografias da mãe.

Descobri desde cedo nas fotografias da minha mãe que a felicidade é uma coleção de instantes suspensos sobre o tempo que só depois de amarelecidos pela ausência se revelam. Nessas fotografias aprendi a não temer o amor e a nostalgia dele, e tornei-me, sem que ela se apercebesse, uma outra espécie de caçadora da luz. [...] Trago no meu sangue que é dela esta calada paixão pelos amores mortos, esta determina- 
ção de só depois entender o essencial, de amar as distâncias como única proximidade do céu. (PEDROSA, 2011, p. 137)

Nas fotografias de Tereza, encontro uma mulher, algumas vezes, de rosto abatido, de olhos fundos, delineados por olheiras, marcas de mulher de traços indígenas, que pariu dezessete filhos em casa, de cócoras, dos quais quatorze sobreviveram. Muitas de suas imagens estão perdendo a nitidez, pela passagem do tempo, mas as rasuras do tempo podem nos fazer pensar sobre o tempo e como ele se inscreve na passagem da história individual de uma pessoa. O que fica dessa vida? Que passos e rastos podemos colher e como podemos fazer isso?

$O$ encontro com a imagem pode nos trazer o que Didi-Huberman (2011) argumenta, citando Maurice Blanchot, uma abertura para a irrealidade, uma aparição propriamente dita. A imagem de Tereza aparece como uma mulher, geralmente, vestida de azul, com a qual pouco convivi e não tenho mais a possibilidade do encontro físico, apenas imagético, e de narrativas ditas ou grafadas nas lembranças, no imaginário ou no revirar das imagens no álbum de fotografias. A imagem traz Tereza como um relâmpago no tempo, preciso captar o que os segundos de entendimento me dão entre olhar as imagens e descrevê-las. Para Didi-Huberman (2011), essa imagem gera um fascínio, mas não porque nos engane, mas porque nos submete à aparição que retorna. Aparição talvez da pessoa, de um sentimento, de uma sensação. Assim:

Ver supõe a distância. [...] ver significa que essa separação tornou-se, porém, encontro. Mas o que acontece quando o que se vê, ainda que à distância, parece tocar-nos por um contato comovente, quando a maneira de ver é uma espécie de toque, quando ver é um contato à distância? (BLANCHOT apud DIDI-HUBERMAN, 2011, p. 29)
Sylvie Meunier através da exposição fotográfica realizada em Paris, no dia 30 de novembro de 2014, intitulada Avant que tu disparaisses, lembra-nos da poética do desaparecimento, lembra-nos do que sobra dos outros, dos rastros e dos restos que escrevem as trajetórias individuais. O que podemos colher das imagens em vias de desaparecer? O que seus rastros suscitam? O que eles fazem arder em nós? O que despertam? A exposição Avant que tu disparaisses:

é uma série de retratos anônimos de fotografias de identidade do fim do século XIX, já envoltas num processo de apagamento. Reunidas, reproduzidas em serigrafias sobre dois suportes de tecidos, uma organza de seda transparente e crepe opaco, que adquirem uma outra existência, um estado flutuante comparável a uma imagem mental, uma lembrança vaga. Ao parar o fluir irreversivel do tempo sobre o papel, Sylvie Meunier define tanto a desaparição e a inefável presença desses personagens em nosso século. Sem reparar ou recompor a fotografia original, ela utiliza sua alteração, sua fragilidade, para solicitar o imaginário daquele que a olha. (CAZENAVE, 2014, s. p., tradução livre). ${ }^{1}$

A que processo combinatório a imagem fotográfica deve a sua existência? À máquina, à pessoa retratada; às maneiras de observar, pensar, expressar, enquadrar, manipular: à existência do tempo, do espaço; aos espectadores? O que arde nas imagens de Tereza? Que signos secretos nelas se escondem ou melhor o que essas imagens mostram? o que sabemos

1 Avant que tu ne disparaisses est une série de portraits d'anonymes, issus de photographies d'identité de la fin du 19 ème siècle déjà engagées dans un processus d'effacement. Réunies, reproduites et sérigraphiées sur deux supports de tissu, un organza de soie transparent et un crêpe, elles acquièrent une autre existence, un état flottant, comparable à une image mentale, un souvenir vague. En arrêtant la sape irréversible du temps sur le papier, Sylvie Meunier fixe à la fois la disparition et l'ineffable présence de ces personnages dans notre siècle. Sans réparer ou recomposer les supports originaux, elle utilise leur altération et leur fragilité pour solliciter l'imaginaire de celui qui regarde. Disponivel em: <http://www.tsldesign.fr/2014-sylvie-meunier/>. Acesso em: 19 abr. 2016. 
e o que não sabemos? Ou o que podemos ainda recuperar? O que sobrevive nas imagens?

[...] a imagem é uma vivência, melhor, uma sobrevivência e, mais: uma supervivência que atravessa o tempo (histórico) e que se nutre de um tempo- passional, pulsional, patético, isto é, humano-anacrônico. (SAMAIN, 2012, p. 33)

Mais do que isso, as imagens pertencem a um tempo imemorial, tempo de várias conjugações, tempo heterogêneo, que desperta em nós ideias, quando as olhamos, como recuperam lembranças até então perdidas, adormecidas e guardadas. Convocam-nos a olhar a nossa história, nos colocam em relação com ela e com o nosso destino. As imagens pensam, pensam como o tempo dos rios e das nuvens, propõe Samain (2012). Isto pode nos fazer lembrar do guardador de rios, personagem de Mia Couto, que fiel a si mesmo dialoga com "invisíveis rios" e tudo ao seu redor se torna parede, onde ele registra os dados da estação hidrométrica, mesmo durante a guerra, fazendo das paredes uma cobertura de inscrições, como se estas fossem um imenso livro de pedra (COUTO, 2011, p. 8).

Convivi quatro anos com Tereza, talvez esse tempo possa ser considerado muito, se não fossem os primeiros quatro anos de minha vida. Sempre me fascinou ouvir o nome de Tereza, talvez por isso eu goste tanto das histórias da santa andarilha espanhola Tereza D'Ávila (padroeira dos professores).

Sobre a Tereza que aqui falamos, nunca soube nada de suas andanças, delas penso que ela teve mais sonhos. Um deles chegou até mim, por uma de suas filhas: "morar na cidade". Mas sei que ela nunca realizou, sobretudo, por causa do marido, que sempre quis morar num sítio, no munícipio de Massapê-CE. Uma sabedoria de vida também chegou até mim, através do relato de Maria Alice, sua filha, em 8 de maio de 2016: “Mamãe sempre que ganhava uma coisa ela dizia que ia usar logo, pois não sabia até quando era viva"

Tereza, a quem pouco conheci, foi-me apresentada como "mãezinha", uma maneira habitual de se referir carinhosamente a uma avó, no interior do Ceará, como em outros lugares do Nordeste. Tereza foi minha avó materna.

Das poucas lembranças, sinto ainda sua presença na cozinha, perto do fogão a lenha, ou sentada no chão, costurando, enquanto eu brincava. A casa, apesar de não mais existir, ainda mora em mim e também é possível lembrar do tempo em que Tereza ali viveu, mesmo que este tempo se esvaia e que dele sobre apenas imagens e ângulos, que nunca mais se aproximarão do vivido e experimentando por ela, nem por mim. No chão daquela cozinha, lembro-me da descrição de Mia Couto, ao narrar as lembranças de Mariano, em Um rio chamado tempo e uma casa chamada terra: "Ali escutei falas e risos, ondulações de vestidos. Naquele lugar recebi os temperos do meu saber[...]" (COUTO, 2003, p. 145).

Reconstituir imagens de Tereza é recompor, nas lembranças, aquela casa que, para mim, foi a casa da infância. Ao encontrar as suas imagens, percebo o quanto esquecemos das imagens, dos lugares, dos acontecimentos, como hoje precisamos de muitas vozes, objetos e imagens para lembrar das experiências vividas. Daquela casa saí e nunca me despedi, mas muito dela ainda mora em mim, talvez nunca tenha me despedido por que: "Em criança não nos despedimos dos lugares. Pensamos que voltamos sempre. Acreditamos que nunca é a última vez [...]" (COUTO, 2009, p. 216).

Cresci ouvindo que na família não tínhamos registros fotográficos dela, não tínhamos imagens dela. Depois fui descobrindo que a questão é que suas filhas achavam que as imagens não eram "muito boas". Então, havia imagens? Indaguei-me. A partir dessa ideia, de que não havia ou que essas imagens existiam, mas não eram 
nítidas, eu comecei a perguntar a suas filhas pelas imagens. Essa pergunta me foi suscitada em 2003, sobretudo por conhecer o trabalho de Fabiana Bruno, que, ao explorar a ideia de vincular o estudo da biografia ao da fotografia, criou um caderno fotobiográfico de sua própria avó (BRUNO, 2009). Em 30 de janeiro desse ano de 2016, por ocasião do aniversário de 80 anos da filha mais velha de Tereza, chamada Maria Delourdes, mostrando o álbum para elas, uma das filhas mais novas, Maria Augusta, perguntou: "como ela conseguiu reunir tantas fotos da mamãe?" Ao que eu respondi: "as fotos estavam com vocês. Separadas, mas estavam com vocês!"

Comecei a perguntar para as suas filhas. Maria Alice entregou-me um envelope com imagens, que até mesmo as outras irmãs desconheciam. Para as duas que moraram perto dela até o fim de sua vida: Maria Dôra e Maria Delourdes, perguntei quais as fotos que elas tinham, e aos poucos comecei a encontrar outras imagens. Muitas dessas fotos estão com marcas da passagem do tempo, já rasuradas, por terem ficado muitos anos em quadros fixados na sala de sua casa, mesmo depois de sua morte, em 1984, e até um pouco depois de 2007, ano que seu marido também falece e, aos poucos, a casa onde viveram e criaram os quatorze filhos foi desmoronando. Com minha mãe, encontrei em binóculos antigos outras imagens e um quadro pintado.

$\mathrm{Na}$ casa tinha um quadro na parede onde as fotos de todas as pessoas da família estavam fixadas, vivos e mortos, a foto de Tereza, mesmo no caixão, com os filhos e o marido ao seu redor, permaneceu ali, durante mais de vinte anos. Foto disposta ao lado de outras tantas, em quadros que percorreram a vida dos familiares e o passar do tempo.

Quando penso no motivo por que as suas filhas falavam que não existiam fotos de Tereza, fico pensando, e tenho como hipótese, de que não era propriamente por que não exis- tiam de fato, suponho que elas queriam falar sobre a visibilidade dessa mulher, a importância dela para as filhas, os seus ensinamentos, os sonhos não realizados, tudo o que dela se apreendeu e que não está projetado nos registros fotográficos que sobreviveram.

Didi-Huberman no livro Écorces, "Cascas", percorre Auschwitz-Birkenau, na Polônia, em junho de 2011, visitando pela primeira vez o campo de extermínio onde seus avós morreram. De "[...] sensação em sensação o fotógrafo-narrador percorre com o olhar procurando restos, ruínas, lembranças e sofrimentos [...]" (CASA NOVA, 2014, p. 66). O filósofo e historiador da arte guarda consigo pedacinhos de casca de bétula, árvore que antigamente se chamava planta da sabedoria, e com esses pedaços ele tenta compor, por meio de fragmentos, o tempo, os pedaços da memória.

Olhei. Olhei pensando que olhar me ajudaria talvez a ler algo que nunca tinha sido escrito. Olhei os três pequenos fragmentos como se fossem as três letras de uma escrita - anterior a todo alfabeto. Ou talvez, como o começo de uma carta a ser escrita, mas para quem? [...] Três fragmentos de tempo. Meu próprio tempo em seus pedaços; um pedaço de memória, essa coisa não escrita que procuro ler; um pedaço do presente, aí sob os meus olhos, sobre a branca página; um pedaço de desejo, a carta para escrever, mas para quem? (DIDI-HUBERMAN apud SAMAIN, 2013, p. 1)

Olhar cascas, rastros, objetos deixados por alguém é uma forma de ler, talvez uma ampla forma de ler, tal como suscita Alberto Manguel, em A última página, como o astrônomo lendo um mapa de estrelas, o zoólogo lendo os rastros de animais na floresta, o jogador lendo os gestos do parceiro de cartas, o organista lendo linhas musicais, os pais lendo sinais no rosto de um bebê, o adivinho procurando as marcas da vida, o tecelão lendo os fios de um tapete, a dançarina lendo os movimentos do coreógrafo, o amante lendo cegamente o corpo amado 
à noite, o psicólogo e o psiquiatra ajudando a ler os sonhos perturbadores de seus pacientes. "Todos esses compartilham com os leitores de livros a arte de decifrar e traduzir signos" (MANGUEL, 1997, p. 19).

\section{Como as imagens pensam:}

\section{trajetos das imagens ou como elas chegam até mim?}

Para Samain (2013), a imagem não é um objeto é um ato diante de nós e que exige de nós uma tomada de posição diante delas, com elas. Nos retratos de Tereza, chega até mim uma foto na qual eu, como neta, estou ao seu lado, e tocame profundamente, como a estou olhando.

Uma fotografia é perda ou encontro? É meIhor estar com os olhos abertos ou fechados? Parece-que fechados enxergamos melhor os movimentos que não só estão nas imagens, mas que são disparados através delas. A fotografia é o brilho reluzente de uma ausência. Um lampejo de um tempo e de uma pessoa que não voltam mais. Se organizo um álbum é antes de tudo para mim e para os que conviveram com Tereza. As imagens potencializam uma experiência afetiva, um caminho que se abre com o olhar. Rastros que se guardam em gestos, existência que se desvela em narrativas, todas depositadas sobre um frágil registro que guarda um acontecimento, um fragmento de passagem de uma vida.

A única foto em que estou com Tereza chega até mim através de um de seus filhos, José Carneiro Neto - que viveu por volta de 30 anos longe da família, em Porto Velho -Rondônia, quando ele retorna ao Ceará. Para ele foi enviada a única foto em que estão presentes a mãe Tereza, as duas irmãs, Assunção e Dôra Carneiro, que com ela viveram até o fim da vida e eu, sua neta Cristina, marcada como a "menina da Creuza", pequena, olhando para ela, como se tentasse decifrá-la. Podemos pensar nas muitas viagens que as fotos fazem até che- garem até nós, ou mesmo por quanto tempo ficam guardadas ou esquecidas.

Sobre isso é importante lembrar o apontamento de Fabiana Bruno:

As fotografias que produzimos circulam, viajam entre parentes, amigos e amantes. Terão, no entanto, uma curta vida visível. Além dos avôs, que ocupam uma parede da casa [...], muitas fotografias, uma vez vistas - não necessariamente olhadas -, voltam ao silêncio de álbuns, caixas de lembranças, bolsos, arquivos - espécie de relicários - onde serão guardadas, antes de ser engavetadas com respeito. Como as grandes árvores, as fotografias precisam envelhecer. (BRUNO, 2013, p. 130)

Fig. 02 - Tereza, filhas e neta (setembro de 1982).

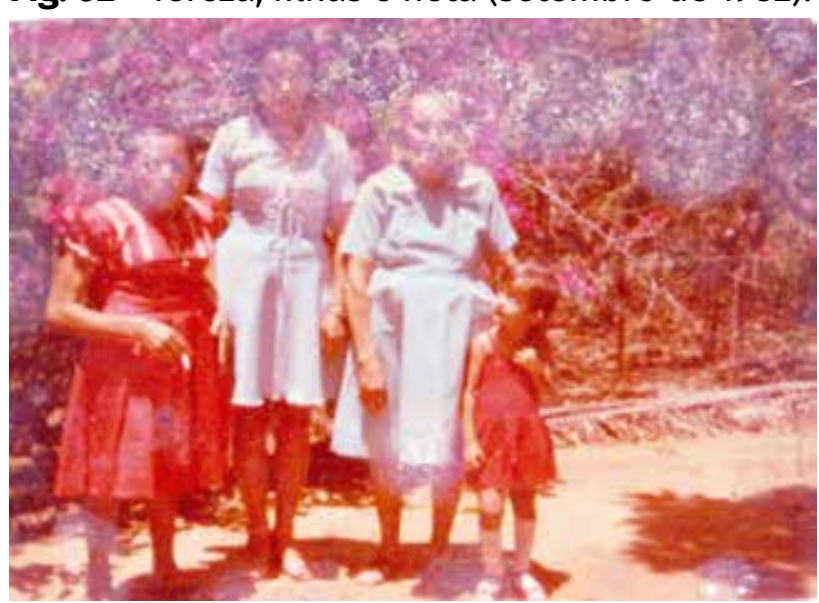

Fonte: Acervo familiar.

Essa foto de Tereza chega até mim depois da volta desse tio. Um dia folheando seu álbum de fotografias, deparo-me com esta imagem. Fui fotografada com Tereza, em setembro de 1982. Não é a única foto dela com os netos, em outra foto, outros dois netos, mais velhos, aparecem ao seu lado. Mas para mim, esta foto é única, e me faz pensar nas muitas viagens de uma foto até que, entre as suas migrações, ela chegue a quem é destinada. Sim, por que, ao abrir o álbum, o meu tio me ofereceu a foto, e essa é a única imagem na qual eu estou ao lado de minha avó Tereza. Essa foto é feita fora da casa, perto de suas flores preferidas: "o pé de riso", comum no Ceará, e outras flores resistentes ao calor e ao tempo seco. 
Para quem destinamos as nossas imagens quando, no seu verso, tecemos dedicatórias? Ou melhor, o que estamos realmente dizendo nessas inscrições? Nesse ato de dar ao outro uma imagem de nós mesmos ou de pessoas importantes para nós? Geralmente, as dedicatórias de fotos são feitas para quem está longe, como é esse o caso. Elas querem pedir que sejamos lembrados, mas, no verso dessa foto, é uma maneira de inscrever o filho distante na rotina familiar, de lembrá-lo de um universo do qual ele faz parte. Essa imagem foi enviada para o único filho que partiu e não voltou, nem mesmo para ver a mãe, quando doente, ou no dia de seu falecimento. As fotos e suas dedicatórias são, assim, uma maneira de inscrever, em seu verso, a história da família e de seus movimentos. Nas fotos, depositam-se resíduos de tempos passados, marcas de mãos cheias de saudades, que as enviam, e de mãos dos que as acolhem como o único meio de não serem esquecidos.

Compor uma fotobiografia é mergulhar nos álbuns, nos quadros, baús e carteiras dos arquivos de família (BRUNO, 2009); é percorrer imagens depositadas no ambiente das relações familiares e trazê-las para pensar, de maneira mais ampla, sobre a existência humana. É também recuperar as inscrições que se associam às fotos, que constroem, através da grafia da letra e da imagem, pertencimentos.

Fig. 03 - Tereza, filhas e neta, verso (setembro de 1982).

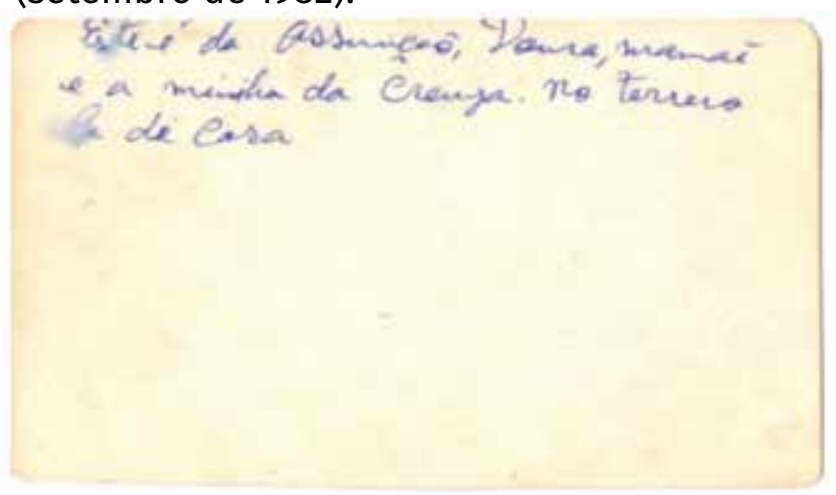

Fonte: Acervo familiar.
Toco a imagem, mas as palavras apenas a contornam, não a dizem, não inteiramente. Reencontro Tereza numa imagem que é contingente, que poderia (ou não) ter sido feita, um rastro de sua passagem, e, nesse caso, de sua presença ao meu lado. Como lembra Barthes (1984): "Eu consultaria imagens em vão, não poderia nunca mais lembrar-me de seus traços (convocá-los, inteiros, a mim) [...]" (BARTHES, 1984, p. 95). Não poderei nunca saber o que sentia ao olhar o seu rosto ou recuperar a sensação de proteção que a imagem me dá, sobretudo, pela sombra onde a foto é feita ou pelo escurecimento deixado pelo tempo na fotografia. Não poderei recuperar o toque de sua mão sobre o meu ombro, mas sei que ela existiu e esteve perto de mim. A imagem não me faz rememorar o passado, "[...] o efeito que ela produz em mim não é o de restituir o que é abolido (pelo tempo, pela distância), mas o de atestar que o que vejo de fato existiu [...]" (BARTHES, 1984, p. 123).

Toda a história de Tereza começa para mim através da foto do dia de sua morte. Talvez aqui a importância de retomar Didi-Huberman (2011) sobre como as nossas lágrimas são importantes na nossa experiência para saber ver as imagens e o que elas nos dizem. Fotografar os mortos é uma prática ainda comum no Nordeste do Brasil, para preservar a recordação sobre os entes queridos, no dia da partida. Essa vai ser a principal foto que sempre marcou as minhas lembranças. É a partir da morte dela, que ela passa a fazer sentido para mim. Lembro-me do anúncio de sua morte, através de uma prima, enquanto eu brincava ao redor de casa. E eu, com quatro anos, tentava entender o que significava aquilo? "Sua avó morreu". Primeiro ela não era minha avó, ela era a mãezinha. Eu me lembro de minha prima me contando, mas eu não tinha ideia do que aquilo queria dizer, não sabia o que era a morte. Depois, a noite, vi seus filhos chorando e lem- 
bro-me de indagar minha mãe se eu precisava chorar também. Nesta época, eu tinha quatro anos de idade. Depois associei que dias antes, pelas dificuldades e a distância da cidade do sítio onde morávamos, meu avô já tinha encomendado o caixão e guardado num quarto, que foi descoberto por uma de suas filhas, que chorou muito, não se conformando com ideia, e me lembro que ela disse que estavam querendo matar a sua mãe. É com a morte que ela ganha sentido na minha vida, passo a recuperar memórias, é a partir dessa morte que eu descubro que tenho uma avó. É a partir dessa morte que eu descubro essa pessoa chamada Tereza. Uma imagem que sempre esteve presente num quadro, na sala de estar; através dessa fotografia, que passou muitos anos entre as fotos dos vivos.

A consciência da perda de Tereza é o que torna possivel recuperar, pela palavra e pelos vestígios das imagens, sua grafia de vida. Uma mulher simples, nordestina, de traços indígenas, casada e mãe de dezessete filhos. Uma mulher que não pôde aprender a ler, que não realizou o sonho de viver numa cidade, mas que, em suas imagens, foi geradora de vida, é uma mão que afaga, um rosto silencioso, quase esboçando um sorriso, que está sempre ao lado do marido, dos filhos e netos. 0 que dela sobrevive, nos faz pensar que o que se narra de uma vida ou nos ajuda a compor uma biografia é menos um todo coerente e mais um aceno, uma lembrança, que vem desgarrada das cronologias e nos devolve uma experiência de alguém que existiu. Uma vida que nos acena com rastros, deixados, esquecidos ou considerados, seja para compreendê-los, segui-los ou rasurá-los.

A partir da história dela, eu começo a descobrir parte também da minha própria história. 0 que ela deixa para mim vai se constituindo a partir de rastros que ela deixou e dos restos, os pequenos vestígios que compõem a sua existência: o vestido, que ela um dia usou, feito por uma de suas filhas Eloisa; a aliança, a medalha, as fotos que tenho buscado para compor seu álbum de fotografias. São essas fotos, o que eu imagino e o que eu lembro, imagens turvas, mas imagens muito fortes e imagens que começam com esse dia da morte, com o que seria o fim. É com esta imagem que parece ser o fim que Tereza ganha existência na minha vida, não só como sua neta, mas como pesquisadora que procura, na antropologia e nos estudos biográficos, um lugar para a fotografia e a composição de álbuns fotográficos.

Fig. 04 - Morte de Tereza, em 11 de março de 1984.

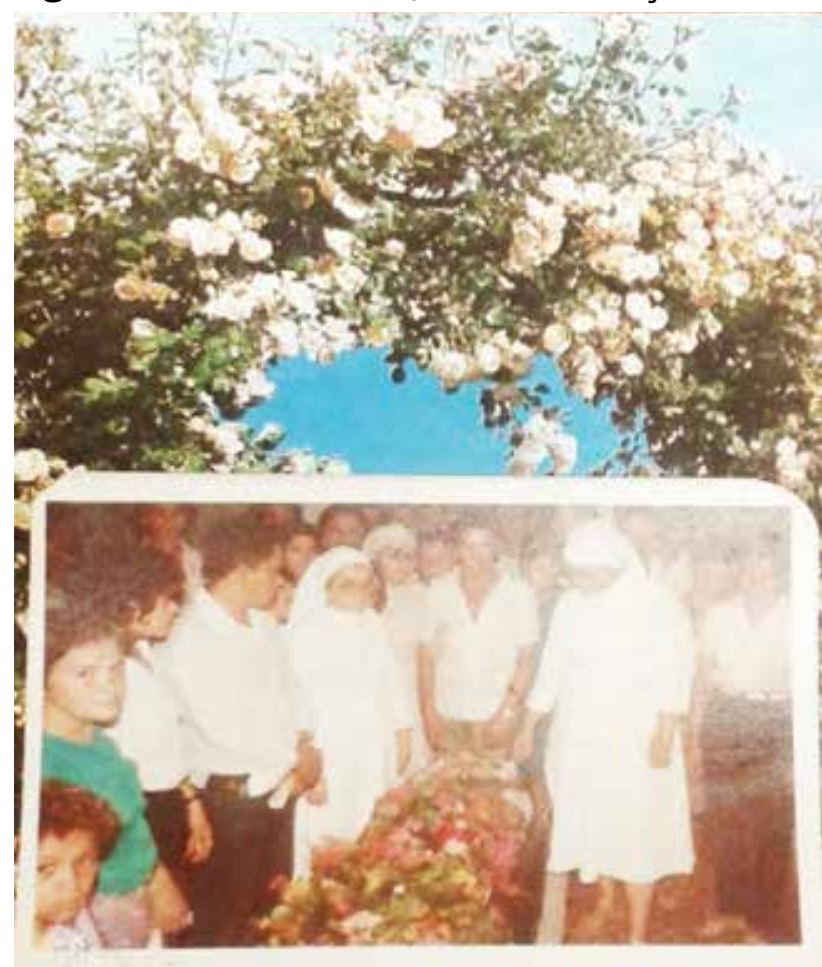

Fonte: Acervo familiar.

Com um de seus vestidos eu me encontrei, para minha surpresa, em abril de 2015 na casa da minha tia Dôra, em Meruoca-CE. Esse vestido foi feito por uma de suas filhas Eloisa, que é vista pelas outras filhas como "o xodó da mamãe"; era uma das filhas mais próximas da mãe e quem fazia os seus vestidos. Este vestido foi herdado por Dôra, junto com a aliança de casamento de Tereza. Ela não é a filha mais velha, mas é a filha que cuidou da mãe até a 
sua morte. Diante dessa foto do vestido, uma das outras filhas mais velhas, que também costurava para a mãe e para as irmãs, Maria Alice, disse: "mas mamãe nem gostava de vestido estampado". Mas a outra filha, Dôra, diz que: "ela gostava sim". Muitos vestidos que Tereza veste são azuis, como esse tem tons de azul. O vestido é uma parte de sua história, sobretudo, como era feito, em casa, pelas filhas, e com a finalidade de viajar nas poucas vezes em que saiu do sítio, em Massapê-CE. Este ela usou quando a filha Eloisa a levou para a cidade de Massapê-CE, e depois para uma viagem até Fortaleza-CE.

Tim Ingold lembra que os "[...] homens fazem a história com as mãos [...]" (INGOLD, 2015, p. 89). São as mãos e os braços que imprimem o que se deseja criar, os projetos de inteligência, a história da tecnologia humana. Isto é muito interessante para pensar aqui, pois Tereza, de acordo com o relato de sua filha Dora, em abril de 2015, que era uma mãe sem habilidades, que não sabia fazer nada, enquanto as filhas costuravam, faziam crochê, cozinhavam. Mas essa filha lembra que ela sabia fazer, muito bem, renda de bilro. Maria Alice, uma de suas filhas, lembra-me uma conversa, no dia 7 de maio de 2016, enquanto nos deslocávamos de carro até minha casa: "O pai da mamãe não quis que nenhuma filha estudasse para que não aprendesse a escrever carta para namorado [...] a mamãe não sabia nem contar dinheiro". Assim, Tereza não estudou, não sabia ler e nem contar.

Com os fios entre os dedos, essa mulher certamente sabia que o encontro desses fios cruzados, por entre as peças de madeira, é que teciam a vida, passando entre os dedos, fio a fio, tecendo a vida, as relações, a sua biografia. Entre as rendas, era a vida que se tecia. Percorrer sua vida é ser testemunha de seus passos e rastros, ouvindo as narrações de seu coti- diano, muitas vezes, possivelmente sofrido e silencioso. Aceitar suas imagens, seus sonhos, sua vida, é talvez fazer com elas sigam adiante, como "num revezamento", como sugere Gagnebin:

Não por culpabilidade ou compaixão, mas porque somente a transmissão simbólica, assumida apesar e por causa do sofrimento indizivel, somente essa retomada reflexiva do passado pode nos ajudar a não repeti-lo infinitamente, mas a ousar esboçar uma outra história, a inventar o presente. (GAGNEBIN, 2006, p. 57)

Mergulhar numa vida que ressurge através de imagens permite-nos olhar a nós mesmos e o nosso próprio tempo, ou mesmo quanto de uma época e de uma pessoa sobrevivem em nós. Tereza teve uma vida dedicada à condição de esposa, cuidando da casa e dos filhos, longe da cidade, que era um de seus sonhos.

Seu nome e as diversas grafias dele revelam como são frágeis os registros institucionais diante de uma vida e também imprecisos em datar vivências, por mais legítimos que tentem ser como registros oficiais de alguém que existiu. As singularidades de uma pessoa, seus gostos e preferências, nos lembram das muitas escritas que deixamos impressas na vida, que ultrapassam a escrita, mas se escrevem nas nossas preferências, nas cores que gostamos, dos sonhos, do que lembram de nós.

Nos objetos, lemos outras grafias que uma vida deixa. Com as imagens, temos uma aparição, que elas realizam, permitindo um encontro com o outro, sobretudo em narrativas. Uma irrealidade, pois torna possivel que vidas há tanto tempo separadas se encontrem no tempo. A separação torna-se imaginariamente um encontro. Com as imagens, os artefatos também nos contam sobre os rastros da vida de uma pessoa. Inscrevem uma biografia numa totalidade, como uma escrita da vida, no seu sentido mais amplo, fazendo com que leiamos 
a vida no orvalho (BARROS, 1998), em cascas (DIDI-HUBERMANN, 2011), pois recuperam partes de contextos vividos e experimentados, interligam-nos a um contexto mais amplo do existir. Como lembra Strathern: "Cada artefato realiza seu próprio tipo de transformação e tem, assim, sua própria agência" (STRATHERN, 2014, p. 500).

As imagens, as roupas, as narrativas e a própria casa constituem-se como monumentos singulares, onde uma vida deixa impressa sua forma de existir. Traços visiveis e invisíveis para contar uma vida e a extensão de seu corpo e de sua pessoa no mundo. Mesmo quando as imagens quase se apagam, podemos ali imaginar, apesar de tudo. Apesar da distância, as imagens e as narrativas criam o encontro. Ver torna-se um contato à distância, onde os olhos se fecham para melhor ver o outro, para melhor compreender o seu caminho.

\section{Referências}

ARTIÈRES, Philippe. Arquivar a própria vida. Revista de Estudos Históricos, v. 11, n. 21, p. 9-34, 1998.

ASSMANN, Aleida. Espaços da recordação. Formas de transformação da memória cultural. Tradução de Paulo Soethe. Campinas, SP: Editora da Unicamp, 2011.

BARROS, Manoel. Retrato do artista quando coisa (1998). Disponivel em: <https://groups.google.com/ forum/\#!topic/saberpolitica/v_xkQiA-bG4>. Acesso em: 25. set. 2016.

BARTHES, Roland. A câmara clara: nota sobre a fotografia. Tradução de Júlio Castañon Guimarães. Rio de Janeiro: Nova Fronteira, 1984.

BARTHES, Roland. Diário de um luto. Tradução de Miguel Serras Pereira. Lisboa: Edições 70, 2009.

BENJAMIN, Walter. As passagens. Tradução do alemão de Irene Aron; Tradução do francês de Cleonice Paes Barreto Mourão. Belo Horizonte: Editora UFMG; São Paulo: Impressa Oficial do Estado de São Paulo, 2009.
Fig. 05 - Vestido de Tereza (abril de 2015).

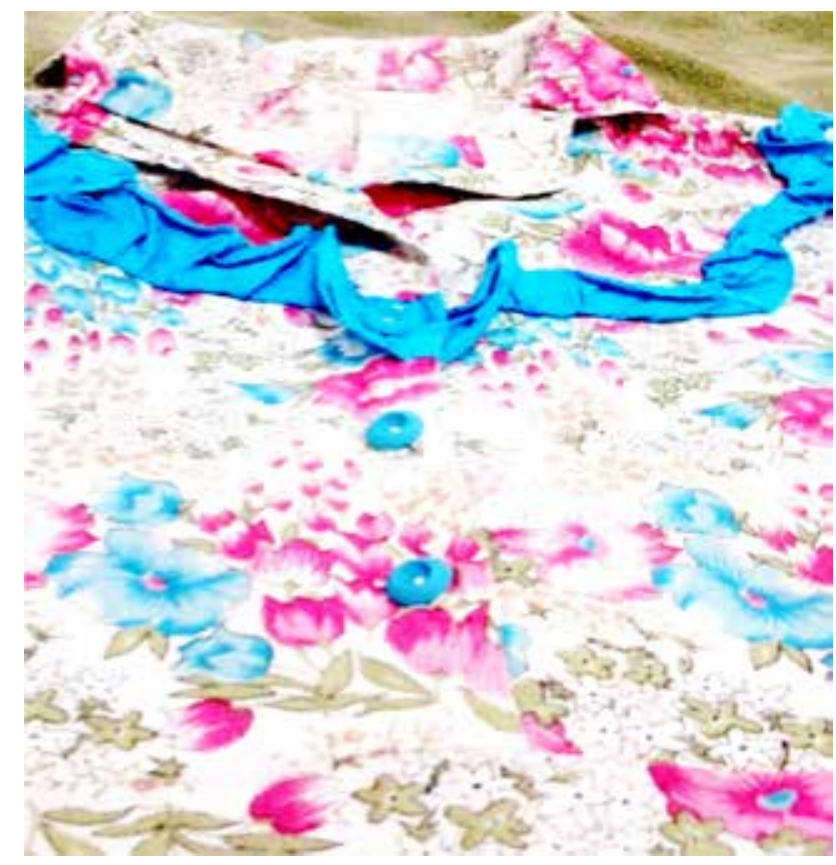

Fonte: Acervo pessoal.

Mas te dou este vestido, Última peça de luxo que guardei como lembrança.

(DRUMMOND, 1985, p. 157)

BENJAMIN, Walter. Rua de mão única. Tradução de Rubens Rodrigues Torres Filho. São Paulo: Editora Brasiliense, 2009. (Obras escolhidas, II).

BRUNO, Fabiana. Imagem-escrita nas fotobiografias. In: COPQUE, Bárbara; PEIXOTO, Clarice Ehlers; LUZ, Gleice Mattos. (Orgs.). Família em imagens. Rio de Janeiro: Editora da FGV, 2013. p.129-142.

BRUNO, Fabiana. Uma antropologia das "supervivências": as fotobiografias. In: SAMAIN, Etienne. (Org.). Como pensam as imagens. Campinas, SP: Editora da Unicamp, 2012. p. 91-106.

BRUNO, Fabiana. Fotobiografia: uma proposta antropológica e estética. Revista Espaço Acadêmico, Maringá-PR, Universidade Estadual de Maringá UEM, v. 14, n. 163, p. 9-20, dez. 2014. Disponivel em: $<$ http://www.periodicos.uem.br/ojs/index.php/EspacoAcademico/article/view/26003>. Acesso em: 15 dez. 2014.

BRUNO, Fabiana. Fotobiografia: por uma meto- 
dologia da estética em antropologia. 2009. $351 \mathrm{f}$. Tese (Doutorado em Multimeios) - Programa de Pós-Graduação em Multimeios, Instituto de Artes, Universidade Estadual de Campinas, Campinas, SP, 2009. Disponível em: <http://www.bibliotecadigital. unicamp.br/document $/$ ? code $=000470077 \&$ opt $=4$. $>$. Acesso em: 07 mai. 2014.

CASA NOVA, Vera. Cascas sobre o papel: memória do dilaceramento. Aletria: Revista de Estudos de Literatura, [s.l.], v. 24, n. 2, p. 64-75, ago. 2014. ISSN 2317-2096. Disponivel em: <http://www.periodicos.letras.ufmg.br/index.php/aletria/article/ view/6941/8689>. Acesso em: 23 abr. 2016.

CAZENAVE, Cécile. Avant que tu disparaisses. Exposition 01. 11. 2014 - 29.11.2014. Disponivel em: <http://www.tsldesign.fr/2014-sylvie-meunier/>. Acesso em: 19 abr. 2016.

COUTO, Mia. Nota introdutória. O Guardador de Rios. In: E se Obama fosse africano?: e outras intervenções. São Paulo: Companhia das Letras, 2011. p. 7-9.

COUTO, Mia. Um rio chamado tempo, uma casa chamada terra. São Paulo: Companhia das Letras, 2003.

Antes de nascer o mundo. São Paulo: Companhia das Letras, 2009.

DIDI-HUBERMAN, Georges. De semelhança a semelhança. Alea, Rio de Janeiro, v. 13, n. 1, p. 26-51, june 2011. Disponivel em: <http://www. scielo.br/scielo.php?script=sci_arttext\&pi$\mathrm{d}=\mathrm{S} 1517-06 \times 2011000100003 \& \operatorname{lng}=$ en $\& \mathrm{nrm}=$ iso $>$. Acesso em: 16 abr. 2016.

DRUMMOND, Carlos. Caso do vestido. In:

Nova reunião: 19 livros de poesia. Rio de Janeiro: José Olympio Editora, 1985. p. 157. Disponível em: <http://www.releituras.com/drummond_vestido. asp>. Acesso em: 20 set. 2015.

GAGNEBIN, Jeanne Marie. Nota da Autora. In: Lembrar, escrever, esquecer. São Paulo: Ed. 34, 2006. p. 11-12.

Verdade e memória do passado. In: Lembrar, escrever, esquecer. São Pau-

lo: Ed. 34, 2006. p. 39-47.

Memória, história, testemunho. In:
Lembrar, escrever, esquecer. São Pau-

lo: Ed. 34, 2006. p. 49-57.

. O rastro e a cicatriz: metáforas da me-

mória. In: Lembrar, escrever, esquecer.

São Paulo: Ed. 34, 2006. p. 107-118.

GINZBURG, Carlo. Sinais: raízes de um paradigma indiciário. In: Mitos, emblemas e sinais. Morfologia e história. Tradução de Federico Carotti. São Paulo: Companhia das Letras, 1989. p.143-179.

GINZBURG, Carlo. Introdução. In: O fio

e os rastros. Tradução de Rosa Freire d'Aguiar e Eduardo Brandão. São Paulo: Companhia das Letras, 2007. p. 7-14.

O inquisidor como antropólogo. In: o fio e os rastros. Tradução de Rosa Freire d'Aguiar e Eduardo Brandão. São Paulo: Companhia das Letras, 2007. p. 280-293.

Feiticeiras e xamãs. In: 0

fio e os rastros. Tradução de Rosa Freire d'Aguiar e Eduardo Brandão. São Paulo: Companhia das Letras, 2007. p. 294-310.

INGOLD, Tim. Estar vivo: ensaio sobre movimento, conhecimento e descrição. Tradução de Fábio Creder. Petrópolis, RJ: Vozes, 2015. (Coleção Antropologia).

KOFES, Suely. Uma trajetória, em narrativas. Campinas, SP: Mercado das Letras, 2001.

MANGUEL, Alberto. Última página. In:

Uma história da leitura. São Paulo: Companhia das Letras, 1997. p. 15-38.

PEDROSA, Inês. Nas tuas mãos. Rio de Janeiro: Objetiva, 2011.

SAMAIN, Etienne. As imagens não são bolas de sinuca. Como pensam as imagens. In: SAMAIN, Etienne. (Org.). Como pensam as imagens. Campinas, SP: Editora da Unicamp, 2012. p. 21-36

. As peles da fotografia: fenômeno, memória/arquivo, desejo. Visualidades, [s.l.], v. 10, n. 1, p. 151-164, mar. 2013. Disponível em: <http:// revistas. ufg.emnuvens.com.br/VISUAL/article/view/23089>. Acesso em: 16 abr. 2016. 
SILVA, Armando. Álbum de família: a imagem de nós mesmos. São Paulo: Editora Senac São Paulo; Edições Sesc SP, 2008.

SONTAG, Susan. Sobre a fotografia. São Paulo: Companhia das Letras, 2004.

STRATHERN, Ann Marilyn. A pessoa como um todo e seus artefatos. In: 0 efeito etnográ-

fico e outros ensaios. São Paulo: Cosac Naify, 2014. p. 487-509.

Recebido em: 02.10.2016

Aprovado em: 20.11.2016

Cristina Maria da Silva é professora adjunta da do Departamento de Ciências Sociais da Universidade Federal do Ceará (UFC). Doutora em Ciências Sociais pela Unicamp. Líder do Grupo de Pesquisa Rastros Urbanos-CNPq. e-mail: crimasbr@yahoo.com.br.

Universidade Federal do Ceará. Av. da Universidade, 2995. Benfica, Fortaleza, CE CEP: 60020-181. 